\section{Flavio Sarno'}

Rafael Moreira Claro"

Renata Bertazzi Levy"'I

Daniel Henrique Bandoniv

Carlos Augusto Monteiro'

Departamento de Nutrição. Faculdade de Saúde Pública. Universidade de São Paulo. São Paulo, SP, Brasil

" Departamento de Nutrição. Universidade Federal de Minas Gerais. Belo Horizonte, MG, Brasil

III Departamento de Medicina Preventiva. Faculdade de Medicina. Universidade de São Paulo. São Paulo, SP, Brasil

iv Departamento de Saúde, Clínica e Instituições, Instituto de Saúde e Sociedade. Universidade Federal de São Paulo. São Paulo, SP, Brasil

\section{Correspondence:}

Carlos Augusto Monteiro

Faculdade de Saúde Pública da Universidade de São Paulo

Av. Dr. Arnaldo, 715

01246-904 São Paulo, SP, Brasil

E-mail: carlosam@usp.br

\section{Estimated sodium intake for the Brazilian population, 2008-2009}

\begin{abstract}
OBJECTIVE: To update estimates of sodium intake in Brazil.

METHODS: We used data from the Brazilian Household Budget Survey of 2008-2009. Records of food purchases of households were converted into nutrients using food composition tables. Mean sodium availability per person per day and mean adjusted availability for a 2,000 kcal daily energy intake were calculated. The contribution of food groups to the total household sodium availability was calculated and compared to results estimated from the 2002-2003 Household Budget Survey.
\end{abstract}

RESULTS: Mean daily sodium available for consumption in Brazilian households was $4.7 \mathrm{~g}$ per 2,000 kcal per day, thus still more than twice the recommended levels of intake for this nutrient. Although most of the sodium available for intake is derived from table salt or salt-based condiments (74.4\%), the fraction derived from processed foods with added salt showed a strong linear increase with household income (12.3\% of total sodium intake in the lower quintile of per capita income distribution and $27.0 \%$ in the upper quintile). There was a reduction in the contribution of salt and salt-based condiments (76.2\% to $74.4 \%)$ and fresh or processed foods without added salt (6.6\% to $4.8 \%$ ) and an increase of processed foods with added salt (15.8\% to $18.9 \%)$ and ready meals (1.4\% to $1.6 \%)$, when compared to results estimated from the 2002-2003 Household Budget Survey.

CONCLUSIONS: Sodium intake in Brazil remains at levels above the recommended maximum for this nutrient in all Brazilian macro regions and income strata. There was stability in the total household sodium availability, and an increase in the fraction from processed foods with addition of salt and ready meals, when comparing 2008-2009 with 2002-2003.

DESCRIPTORS: Sodium Chloride. Sodium, Dietary. Food Habits. Nutrition Policy. Socioeconomic Factors. Nutrition Surveys. Budget. Population Survey. 


\section{INTRODUCTION}

Excessive sodium intake is one of the main risk factors for high blood pressure. ${ }^{22}$ On a global scale, 7.6 million premature deaths, around $54 \%$ of strokes and $47 \%$ of ischemic heart disease are attributed to high blood pressure. ${ }^{10}$ High sodium intake is also linked to brain strokes, left ventricular hypertrophy and renal diseases. ${ }^{6}$

Reducing sodium intake is linked with lower blood pressure levels in both hypertensive and normotensive individuals and with a lower risk of cardiovascular disease. Cost-effectiveness analyses report that even modest decreases in the population's sodium intake would have beneficial health effects and lead to a large reduction in the costs of treating diseases. ${ }^{7,21}$

In spite of this, for the majority of the adult population in many countries ${ }^{3}$, sodium intake is above $2.3 \mathrm{~g} / \mathrm{day}$, whereas the maximum daily intake recommended by the World Health Organization (WHO) is 2 g/day. ${ }^{a}$

In Brazil, it is estimated, based on data collected in the Household Budget Survey (POF) in 2002-2003, that the daily salt intake in households is $4.7 \mathrm{~g} /$ person/day, over twice the recommended daily limit for this nutrient. ${ }^{19}$

This study aimed to update estimates of sodium intake in Brazil.

\section{METHODS}

The data collected by the POF, carried out by the Brazilian Institute of Geography and Statistics (IBGE), between May 2008 and May 2009 using a probabilistic sample of 55,970 households, were used as the basis of this study. ${ }^{\text {b }}$

The POF 2008-2009b used complex cluster sampling, drawing census tracts in the first stage and households in the second. To draw the census tracts, the researchers proceeded to group the set of 12,800 tracts, the so-called Master Sample of Household Surveys (or Common Sample), with the aim of stratifying the households with geographic and socio-economic homogeneity. This grouping considered the location of the tracts (region, state, capital or interior, urban or rural area) and the spectrum of variation in the economic level of the families residing within each geographic locus, based on the head of household income (data obtained from the 2000 Demographic Census). The number of tracts drawn for each strata were proportional to the total number of households in the strata, with the proviso of keeping at least three tracts in the sample of each strata. Households in each tract were drawn by simple random sampling, without replacement. The number of households interviewed, per sector, was fixed according to the area of the research (12 households in the urban tracts, 16 in the rural tracts). The household interviews, within each strata, were uniformly distributed throughout the four quarters (three-month-periods) of the study, reproducing seasonal variations in income and spending on food (and other products) in each strata.

The short reference period used by the POF for registering food spending in each household (seven days) did not allow for the patterns of typical food spending to be known for each of the households studied. Therefore, the $\mathrm{POF}^{\mathrm{b}}$ estimates refer to aggregates of households representing regions, states or even municipalities (such as state capitals). It was decided to use aggregates of households as the unit of the study, corresponding to the households studied in each of the 550 sample strata of the study. Thus, the homogeneity of the units of study, from a spatial and socio-economic point of view was ensured and the pattern of spending on food throughout 12 months may be reliably known.

The basic data from the POF 2008-2009 ${ }^{\mathrm{b}}$ analyzed in this study refer to food and drinks bought to be consumed at home, by the unit of consumption (household) for seven consecutive days and recorded daily in the collective spending diary by a member of the household or by the IBGE interviewer. Quantity, unit of measurement (or equivalent in weight or volume), cost, place bought and the form in which it was paid for (monetary or non-monetary) were recorded for each acquisition.

When necessary, the non-edible part of the gross quantity of each foodstuff bought by the household was excluded, using factors of correction estimated by the IBGE. . The edible quantity of each foodstuff was converted into energy (kcal) and sodium (grams) using the Brazilian Table of Food Composition - Version2 ${ }^{\mathrm{d}}$ or, failing this, the United States official table of food composition, version 15. ${ }^{\text {e }}$ For foodstuffs preserved using salt, such as beef jerky, dried and sun-dried meat

\footnotetext{
a World Health Organization. WHO Forum on Reducing Salt Intake in Populations. Reducing salt intake in populations: report of a WHO forum and technical meeting, 5-7 October 2006, Paris; 2006.

${ }^{b}$ Instituto Brasileiro de Geografia e Estatística. Pesquisa de Orçamentos Familiares 2008-2009. Avaliação nutricional da disponibilidade domiciliar de alimentos no Brasil. Rio de Janeiro; 2010.

c Instituto Brasileiro de Geografia e Estatística. Estudo Nacional da Despesa Familiar - ENDEF: dados preliminares, consumo alimentar, antropometria. Rio de Janeiro; 1977.

d Universidade Estadual de Campinas. Núcleo de Estudos e Pesquisas em Alimentação. Tabela brasileira de composição de alimentos. Versão II. 2. ed. Campinas; 2006.

e United States. Department of Agriculture, Agricultural Research Service. National nutrient database for standard reference,

Nutrient Data Laboratory Home Page. Beltsville; 2005 [cited 2011 Jul 31]. Available from: http://www.ars.usda.gov/main/site_main.

htm?modecode=12-35-45-00 (Release, 18)
} 
and salted fish, the equivalent quantity and sodium concentrate of the de-salted food was considered.

The data on the foodstuffs were divided into 98 different groups in the POF 2008-2009. Based on this division and after being converted into energy, the records were reunited in the food groups: salt and salt based condiments; processed food with added salt (bread, processed meat and canned vegetables); fresh foods or processed foods without added salt (pasteurized milk, fresh or frozen meat, fruit and vegetables and ready meals (ready meals based on meat or pasta).

The daily available energy and sodium per person for each unit of study (household strata) were calculated. The available sodium adjusted for total energy intake of 2,000 calories, corresponding to the recommended daily energy intake/person for Brazil ${ }^{\mathrm{f}}$ to circumvent the fact that it was the availability of salt in the household rather than the actual intake of this nutrient which was analyzed (eating out was not considered, nor was the fraction of foodstuffs bought but not consumed).

Means of the availability of sodium in the POF 2008-2009 ${ }^{\text {b }}$ (and respective standard errors) are shown for the country as a whole, for the five geographical macro regions, disaggregated into urban and rural situations and for quintiles of per person income distribution observed in the 550 strata of this study. The share of food groups in the household availability of sodium was evaluated according to quintiles of the distribution of household income. The trend for this share was evaluated using linear regression models, having the value of the share of the particular food group in the household availability of sodium as an outcome and quintiles of distribution of income as explanatory variable. Values of $\mathrm{p}<0.05$ were considered significant.

The evolution of percentage share of the food groups in household availability of sodium is described for the country as a whole, comparing the data from the POF 2002-2003ㅁ with that of 2008-2009. ${ }^{\text {b }}$

The procedures adopted to estimate the household availability of sodium in the POF 2002-2003, identical to those used in this study, are described in an earlier publication. ${ }^{19}$ The Stata version 9.2 application was used to analyze data and the sample weights of the study units were considered.

\section{RESULTS}

Household availability of sodium in Brazil was $4.7 \mathrm{~g} /$ person/day, adjusted for energy intake of 2,000 $\mathrm{kcal}$, more than twice the recommended maximum daily intake of $2 \mathrm{~g} /$ day. Availability was above $4 \mathrm{~g}$ in all regions, being higher in strata of rural households. The lowest was found in urban households in the Southeast and the highest in rural households in the North (Table 1).

Household availability of sodium adjusted for energy intake of 2,000 kcal/person/day decreased with income, with a difference of around $20 \%$ between the highest and lowest quintile of income distribution per person for the Brazilian population. However, availability was high in all income groups, exceeding maximum recommended sodium intake (Table 2).

Around three quarters of total sodium available for consumption was derived from the purchase of table salt and salt based condiments. This contribution decreased significantly with increased income, varying from $83.7 \%$ to $63.5 \%$ between the highest and lowest quintiles of income. The contribution of processed foods and ready meals increased significantly and intensely, more than doubling between the highest and lowest income quintiles (12.9\% to 30.3\%) (Table 3).

Household availability of sodium remained stable between the POF 2002-2003 and POF 2008-2009 (4.7 g/2,000 kcal). The contribution of table salt and salt based condiments (from 76.2\% to $74.4 \%$ ) decreased and that of processed foods with added salt and of ready meals increased (from 17.2\% to 20.5\%) (Figure).

\section{DISCUSSION}

The quantity of sodium available for consumption in Brazilian households is more than double the maximum daily limit recommended by the WHO. Excessive availability of sodium continues to be seen in all regions of the country, in both urban and rural areas and in all income classes.

Although sodium available for consumption comes mainly from table salt and salt based condiments, almost $1 /{ }_{5}$ of the mineral comes from processed foods with added salt, whose share exceeded $25 \%$ in higher income households.

Although remaining at a high, but stable, level between the POF 2002-2003 ${ }^{19}$ and 2008-2009, the origin of the sodium available in Brazilian households has changed: there was an increase in the fraction deriving from processed foods with added salt and ready meals, and a decrease in the relative share of table salt and salt based condiments.

The efficacy of the adjustment for a fixed availability of 2,000 kcal/person/day assumes that meals eaten

\footnotetext{
†Ministério da Saúde. Secretaria de Atenção à Saúde. Departamento de Atenção Básica. Guia alimentar para a população brasileira: promovendo a alimentação saudável. Brasília (DF); 2008. (Série A. Normas e Manuais Técnicos)

g Instituto Brasileiro de Geografia e Estatística. Pesquisa de orçamentos familiares 2002-2003: aquisição alimentar domiciliar per capita. Rio de Janeiro; 2004
} 
Table 1. Household availability of energy and sodium, according to macro region and rural or urban location. Brazil, 2008 to 2009.

\begin{tabular}{|c|c|c|c|c|c|c|}
\hline \multirow{2}{*}{ Region } & \multicolumn{2}{|c|}{ Energy (kcal/person/day) } & \multicolumn{2}{|c|}{ Sodium (g/person/day) } & \multicolumn{2}{|c|}{ Sodium (g/person/2.000 kcal) } \\
\hline & Mean & Standard error & Mean & Standard error & Mean & Standard error \\
\hline \multicolumn{7}{|l|}{ North } \\
\hline Urban & $1,836.4$ & 56.1 & 4.9 & 0.4 & 5.3 & 0.3 \\
\hline Rural & $2,299.0$ & 148.0 & 10.5 & 2.1 & 9.2 & 1.9 \\
\hline Total & $1,850.1$ & 54.2 & 5.1 & 0.4 & 5.4 & 0.3 \\
\hline \multicolumn{7}{|l|}{ Northeast } \\
\hline Urban & $1,542.6$ & 40.1 & 3.5 & 0.1 & 4.5 & 0.1 \\
\hline Rural & $1,835.5$ & 53.4 & 5.0 & 0.4 & 5.6 & 0.3 \\
\hline Total & $1,641.7$ & 34.8 & 4.0 & 0.2 & 4.9 & 0.2 \\
\hline \multicolumn{7}{|l|}{ Southeast } \\
\hline Urban & $1,515.7$ & 52.2 & 3.1 & 0.3 & 4.0 & 0.3 \\
\hline Rural & $1,956.0$ & 74.1 & 4.5 & 0.3 & 4.5 & 0.2 \\
\hline Total & $1,626.1$ & 50.0 & 3.5 & 0.2 & 4.1 & 0.2 \\
\hline \multicolumn{7}{|l|}{ South } \\
\hline Urban & $1,761.3$ & 52.0 & 4.3 & 0.2 & 4.9 & 0.2 \\
\hline Rural & 2,232.4 & 131.7 & 6.6 & 0.7 & 5.9 & 0.4 \\
\hline Total & 1,895.6 & 54.3 & 5.0 & 0.3 & 5.2 & 0.2 \\
\hline \multicolumn{7}{|l|}{ Midwest } \\
\hline Urban & $1,682.8$ & 79.8 & 5.0 & 0.9 & 5.8 & 1.0 \\
\hline Rural & 1,969.6 & 184.5 & 7.6 & 2.6 & 6.7 & 1.8 \\
\hline Total & $1,756.4$ & 75.6 & 5.7 & 0.9 & 6.1 & 0.9 \\
\hline \multicolumn{7}{|l|}{ Brazil } \\
\hline Urban & $1,600.9$ & 31.2 & 3.7 & 0.2 & 4.5 & 0.2 \\
\hline Rural & $1,964.1$ & 43.8 & 5.3 & 0.3 & 5.3 & 0.2 \\
\hline Total & $1,696.9$ & 28.3 & 4.1 & 0.2 & 4.7 & 0.1 \\
\hline
\end{tabular}

out have similar sodium levels to homemade meals and that the fraction of waste is independent of its sodium content.

Although no Brazilian studies comparing sodium levels in homemade meals and those eaten out were found, it is recognized that meals eaten outside of the home tend to have a higher levels of sodium. ${ }^{2}$ If this phenomenon is also true of Brazil, the population's real sodium intake may be even higher than that estimated in this study.

Therefore, sodium intake may have been underestimated, especially in urban areas, where energy intake outside of the home reached an average $17.5 \%$ (9.8\% for those in rural areas), according to the POF 2008-2009. . Thus, the inverse relationship between household income and sodium may decrease if eating out were considered, as this is usually more common in individuals with higher income.
Two domestic cooking habits may be the reason why waste of table salt is higher than that of other items in the diet: cooking foods in salt water and salting food. In Brazil, foods usually cooked in salt water are pasta, potatoes and carrots. Considering the mean quantities Brazilian households purchase of these foodstuffs, ${ }^{i}$ the typical concentration of salt in the salted water ${ }^{5,17}$ and the fraction of salt added to these items after cooking, ${ }^{18}$ the consumption of these foodstuffs account for waste of around 5.5\% of the total salt purchased by Brazilian households. However, such wastage would not be sufficient to modify this study's conclusions on the excessive amount of salt consumed in Brazil.

Another possible source of salt wastage is its use in home salting. This process is uncommon in urban areas, indicating its minimal effect on estimates made about the almost $85 \%$ of Brazilians who live in cities. It is possible that this practice is more common in rural areas and this may explain the higher availability of salt observed in rural households.

${ }^{\mathrm{h}}$ Instituto Brasileiro de Geografia e Estatística. Pesquisa de orçamentos familiares 2008-2009: análise do consumo alimentar pessoal no Brasil. Rio de Janeiro; 2011

'Instituto Brasileiro de Geografia e Estatística. Pesquisa de orçamentos familiares 2008-2009: aquisição alimentar domiciliar per capita Brasil e grandes regiões. Rio de Janeiro; 2010. 
Table 2. Household availability of energy and sodium, according to quintiles of income distribution per person. Brazil, 2008 to 2009.

\begin{tabular}{lcccccc}
\hline \multirow{2}{*}{$\begin{array}{l}\text { Quintile of } \\
\text { income }\end{array}$} & \multicolumn{2}{c}{ Energy $(\mathrm{kcal} /$ person/day) } & \multicolumn{2}{c}{ Sodium $(\mathrm{g} /$ person/day) } & \multicolumn{2}{c}{ Sodium $(\mathrm{g} /$ person/2,000 kcal) } \\
\cline { 2 - 6 } & Mean & Standard error & Mean & Standard error & Mean & Standard error \\
\hline $1^{\circ}$ & $1,777.7$ & 52.0 & 4.8 & 0.3 & 5.4 & 0.2 \\
$2^{\circ}$ & $1,690.0$ & 47.9 & 4.2 & 0.3 & 4.9 & 0.3 \\
$3^{\circ}$ & $1,608.6$ & 75.3 & 4.0 & 0.5 & 4.7 & 0.4 \\
$4^{\circ}$ & $1,715.1$ & 81.9 & 3.9 & 0.3 & 4.4 & 0.2 \\
$5^{\circ}$ & $1,692.9$ & 39.0 & 3.7 & 0.2 & 4.3 & 0.2 \\
Brasil & $1,696.9$ & 28.3 & 4.1 & 0.2 & 4.7 & 0.1 \\
\hline
\end{tabular}

The short reference period (one week) for collecting data on the purchase of elements in each household, according to the POF, may constitute an important limitation of this study. In order to minimize this effect, homogenous groups of households, with regards to location and socio-economic characteristics (strata) were adopted as the unit of analysis, studied over 12 months.

In spite of these limitations, studies comparing POF data with those obtained from surveys of individuals' consumption indicate considerable agreement between the methods. ${ }^{15}$ Data on the household availability of sodium better reflect household intake of this nutrient compared with surveys of individuals' consumption, as the POF evaluates consumption of ingredients used in preparing food more accurately. ${ }^{1}$

Developed countries, where salt added during the processing of food is the dominant source of sodium in the diet, are implementing strategies to reduce sodium intake in order to control high morbidity and mortality from non-communicable chronic diseases. These strategies include: public awareness campaigns and education for the public and health care professionals, information on sodium content on food labels, establishing norms and goals for sodium content in processed foods, food industry agreements to limit sodium content in their products and regulating advertising of foods with high sodium content. ${ }^{20}$ The results show reductions in sodium intake of almost 25\% in Finland ${ }^{9}$ and around 14\% in England. ${ }^{12}$

The recent national strategy to reduce sodium intake in Brazil, formulated by the Ministério da Saúde,

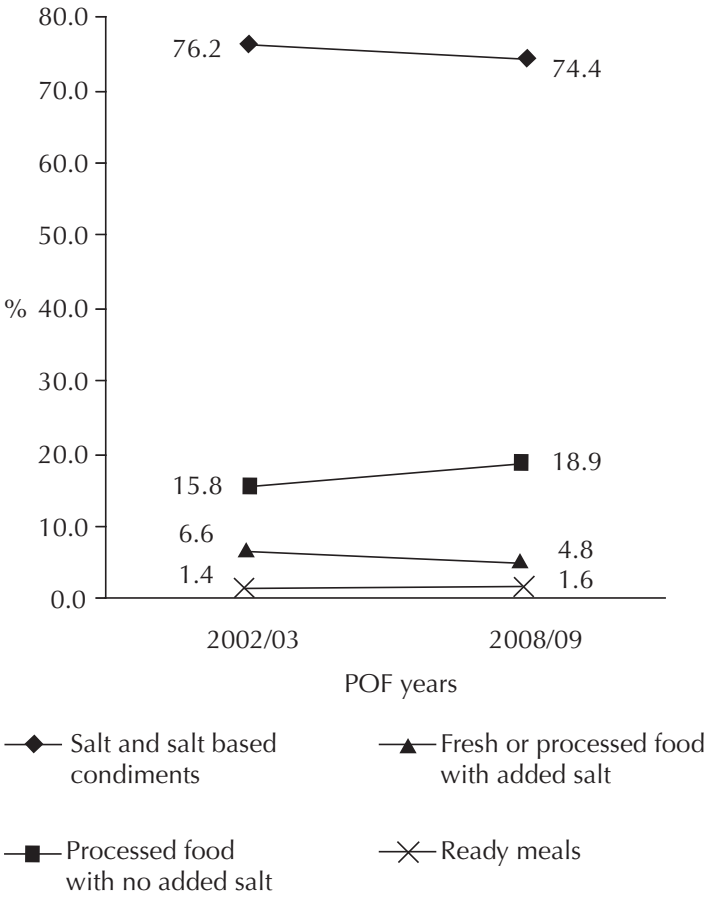

Figure. Food groups share (\%) of the total household availability of sodium, according to Household Budget Surveys. Brazil, 2002 to 2003 and 2008 to 2009.

included campaigns aimed at reducing the sodium content of processed foods, ${ }^{\mathrm{j}, \mathrm{k}}$ placing nutritional information in food products sold in snack bars and restaurants ${ }^{1}$ and actions aimed at reducing the addition of sodium to foods prepared at home and by food services. $^{\mathrm{m}, \mathrm{n}}$

j Ministério da Saúde. Termo de Compromisso no 004/2011. Diario Oficial Uniao. 08 abr 2011 [cited 2012 Feb 5]. Available from: http://189.28.128.100/nutricao/docs/geral/termo_compromisso_004_2011.pdf

${ }^{k}$ Agência Nacional de Vigilância Sanitária. Perfil nutricional dos alimentos processados. Brasília (DF); 2012 [cited 2012 Feb 18]. Available from: http://portal.anvisa.gov.br/wps/wcm/connect/c476ee0047457a6e86efd63fbc4c6735/INFORME+T\%C3\%89CNICO+n++43+-+2010+PERFIL+NUTRICIONAL+_2_.pdf?MOD=AJPERES (Informe técnico, 43).

'Agência Nacional de Vigilância Sanitária. Termo de compromisso de ajustamento de conduta para informação nutricional. Brasília (DF); 2010 [cited 2012 Jun 3]. Available from: http://portal.anvisa.gov.br/wps/content/Anvisa+Portal/Anvisa/Inicio/Alimentos/Assuntos+de+Interesse/ Rotulagem/Termo+de+compromisso+de+ajustamento+de+conduta+para+informacao+nutricional

m Agência Nacional de Vigilância Sanitária. Documento de referência para guias de boas práticas nutricionais. Brasília (DF); 2012 [cited 2012 Feb 18].Available from: http://portal.anvisa.gov.br/wps/wcm/connect/28fe0e0049af6b5b96e1b66dcbd9c63c/2Documentobase paraGuiasdeBoasPraticasNutricionais2.pdf?MOD=AJPERES

n Ministério da Saúde. Campanha busca conscientizar população em relação ao uso excessivo de sal. Brasília (DF); 2011 [cited 2012 Feb 18]. Available from: http://portal.saude.gov.br/portal/aplicacoes/noticias/default.cfm?pg=dspDetalheNoticia\&id_area=1529\&CO_NOTICIA=13050 
Table 3. Distribution (\%) of household availability of sodium in quintiles of distribution of household income per person, according to food groups. Brazil, 2008 to 2009.

\begin{tabular}{lcccccc}
\hline \multirow{2}{*}{ Food group } & \multicolumn{5}{c}{ Quintile of income per person } \\
\cline { 2 - 7 } & Brazil & $1^{\circ}$ & $2^{\circ}$ & $3^{\circ}$ & $4^{\circ}$ & $5^{\circ}$ \\
\hline Salt and salt based condiments & 74.4 & 83.7 & 77.2 & 74.9 & 70.8 & $63.5^{\mathrm{b}}$ \\
Processed food with added salt & 18.9 & 12.3 & 17.4 & 18.8 & 21.3 & $27.0^{\mathrm{b}}$ \\
Fresh or processed food with no added salt & 4.8 & 3.5 & 4.3 & 4.9 & 5.6 & $6.1^{\mathrm{b}}$ \\
Ready meals & 1.6 & 0.6 & 1.3 & 1.2 & 2.2 & $3.3^{\mathrm{a}}$ \\
\hline
\end{tabular}

a $p<0.05$

${ }^{\mathrm{b}} \mathrm{p}<0.01$

The results of the agreements signed by the food industry will depend, in addition to broadening the agreed aims, on the existence of mechanisms to monitor and penalize the non-accomplishment of these goals and on the control of other chemical products, (e.g., preservatives) or nutrients (sugar or fat) added in place of sodium. Monitoring and evaluating the strategies implemented should be carried out independently to avoid possible conflicts of interest. Moreover, even though processed foods have reduced their sodium content, they may still have low levels of potassium, calcium and magnesium, other nutrients important in regulating blood pressure. ${ }^{8}$

Sodium intake has been shown to be excessive in the majority of countries; however, the source of food intake of this mineral vary according to the country studied. The greater part of sodium consumed in European countries and in the United States and Canada comes from processed foods. In Japan and China, the main source is from salt and salt based condiments added to dishes. ${ }^{3}$

The first studies on sodium intake in Brazil took place in the 1970s, with results varying between $3.1 \mathrm{~g}$ and 5.9 g per day, but always above the maximum daily limit recommended by the WHO., ${ }^{4,11,13,14,16,19}$ In 2008-2009, the POF analyzed the pattern of individual food consumption of the participants $>10$ years old, using two food diaries in a sub sample of 13,569 households. ${ }^{\text {h }}$ Daily sodium intake varied between $3.2 \mathrm{~g}$ and $3.7 \mathrm{~g}$ in men and $2.6 \mathrm{~g}$ to $2.9 \mathrm{~g}$ in women, depending on the age group analyzed. The lower values, compared to this study, may be due to limitations of the method of evaluating individual consumption in the POF 2008-2009, ${ }^{\mathrm{h}}$ as data on use of table salt is not included and the standard values rather than those directly reported by the individuals on the quantity of salt added to meals are adopted.

In conclusion, sodium intake in Brazil remains above the recommended daily maximum for this nutrient in all macro regions and income classes. There was a tendency for the relative share of table salt and salt based condiments and fresh or processed foods without added salt to decrease and an increase in the proportion of sodium coming from processed food and ready meals over the last five years. 


\section{REFERENCES}

1. Becker W. Comparability of household and individual food consumption data--evidence from Sweden. Public Health Nutr. 2001;4(5B):1177-82.

2. Beydoun MA, Powell LM, Wang Y. Reduced awayfrom-home food expenditure and better nutrition knowledge and belief can improve quality of dietary intake among US adults. Public Health Nutr. 2009;12(3):369-81.

3. Brown IJ, Tzoulaki I, Candeias V, Elliott P. Salt intakes around the world: implications for public health. Int J Epidemiol. 2009;38(3):791-813. DOI:http://dx.doi.org/10.1093/ije/dyp139

4. Claro RM, Machado FMS, Bandoni DH. Evolução da disponibilidade domiciliar de alimentos no município de São Paulo no período de 1979 a 1999. Rev Nutr. 2007;20(5):483-90. DOI: http://dx.doi.org/10.1590/S1415-52732007000500004

5. Fisberg RM, Villar BS. Manual de receitas e medidas caseiras para cálculo de inquéritos alimentares. São Paulo: Signus; 2002.

6. He FJ, MacGregor GA. Reducing population salt intake worldwide: from evidence to implementation. Prog Cardiovasc Dis. 2010;52(5):363-82. DOI:http://dx.doi.org/10.1016/j.pcad.2009.12.006

7. He FJ, Macgregor GA. Salt intake, plasma sodium, and worldwide salt reduction. Ann Med. 2012;44(Suppl 1):127-37. DOI:http://dx.doi.org/10.3109/07853890.2012.660495

8. Karppanen $\mathrm{H}$, Karppanen $\mathrm{P}$, Mervaala E. Why and how to implement sodium, potassium, calcium, and magnesium changes in food items and diets? I Hum Hypertens. 2005;19Suppl 3:S109. DOI:http://dx.doi.org/10.1038/sj.jhh.1001955

9. Laatikainen T, Pietinen P, Valsta L, Sundvall J, Reinivuo $\mathrm{H}$, Tuomilehto J. Sodium in the Finnish diet: 20-year trends in urinary sodium excretion among the adult population. Eur J Clin Nutr. 2006;60(8):965-70. DOI:http://dx.doi.org/10.1038/sj.ejcn.1602406

10. Lawes CM, Vander Hoorn S, Rodgers A. Global burden of blood-pressure-related disease, 2001. Lancet. 2008;371(9623):1513-8. DOI:http://dx.doi.org/10.1016/S0140-6736(08)60655-8

11. Micheli ET, Rosa AA. Estimation of sodium intake by urinary excretion and dietary records in children and adolescents from Porto Alegre, Brazil: a comparision of two methods. Nutr Res. 2003;23(11):1477-87. DOI:http://dx.doi.org/10.1016/S0271-5317(03)00157-X
12. Millett C, Laverty AA, Stylianou N, BibbinsDomingo K, Pape UJ. Impacts of a national strategy to reduce population salt intake in England: serial cross sectional study. PLoS One. 2012;7(1):e29836. DOI:http://dx.doi.org/10.1371/journal.pone.0029836

13. Molina M, Cunha R, Herkenhoff L, Mill J. Hipertensão arterial e consumo de sal em população urbana. Rev Saude Publica. 2003(6):743-50. DOI: http://dx.doi.org/10.1590/S0034-89102003000600009

14. Moraes RS, Fuchs FD, Dalla Costa F, Moreira LB. Familial predisposition to hypertension and the association between urinary sodium excretion and blood pressure in a population-based sample of young adults. Braz / Med Biol Res. 2000;33(7):799-803. DOI: http://dx.doi.org/10.1590/S0100-879X2000000700010

15. Naska A, Vasdekis VG, Trichopoulou A. A preliminary assessment of the use of household budget survey data for the prediction of individual food consumption. Public Health Nutr. 2001;4(5B):1159-65.

16. Pavan L, Casiglia E, Pauletto P, Batista SL, Ginocchio G, Kwankam MM, et al. Blood pressure, serum cholesterol and nutritional state in Tanzania and in the Amazon: comparison with an Italian population. J Hypertens. 1997;15(10):1083-90. DOI: http://dx.doi.org/10.1097/00004872-199715100-00006

17. Pinheiro ABV, Lacerda EMA, Benzecry EH, Gomes MCS, Costa VM. Tabela para avaliação de consumo alimentar em medidas caseiras. 3. ed. Rio de Janeiro: Atheneu; 1993.

18. Sánchez-Castillo CP, James WP. Defining cooking salt intakes for patient counselling and policy making. Arch Latinoam Nutr. 1995;45(4):259-64.

19. Sarno F, Claro RM, Levy RB, Bandoni DH, Ferreira SR, Monteiro CA. Estimativa de consumo de sódio pela população brasileira, 2002-2003. Rev Saude Publica. 2009;43(2):219-25. DOI: http://dx.doi.org/10.1590/S0034-89102009005000002

20. Webster JL, Dunford EK, Hawkes C, Neal BC. Salt reduction initiatives around the world. J Hypertens. 2011;29(6):1043-50. DOI: http://dx.doi.org/10.1097/HJH.0b013e328345ed83

21. Wang G, Labarthe D. The cost-effectiveness of interventions designed to reduce sodium intake. J Hypertens. 2011;29(9):1693-9. DOI: http://dx.doi.org/10.1097/HJH.0b013e328349ba18

22. Zhao D, Qi Y, Zheng Z, Wang Y, Zhang XY, Li HJ, et al. Dietary factors associated with hypertension. Nat Rev Cardiol. 2011;8(8):456-65. DOI:http://dx.doi.org/10.1038/nrcardio.2011.75

Claro RM received a Post-Doctorate grant from the Fundação de Amparo à Pesquisa do Estado de São Paulo (FAPESP Process no 2010/08421-7).

The authors declare that there are no conflicts of interest. 